\title{
RT-PCR Detection of Seedborne Cowpea aphid-borne mosaic virus in Peanut
}

\author{
A. G. Gillaspie, Jr., USDA-ARS, Plant Genetic Resources Conservation Unit, Griffin, GA 30223; G. Pio-Ribeiro \\ and G. P. Andrade, Universidade Federal de Rural Pernambuco, Recife, Brazil; and H. R. Pappu, Department of \\ Plant Pathology, University of Georgia, Coastal Plain Experimental Station, Tifton 31793
}

\begin{abstract}
Gillaspie, A. G., Jr., Pio-Ribeiro, G., Andrade, G. P., and Pappu, H. R. 2001. RT-PCR detection of seedborne Cowpea aphid-borne mosaic virus in peanut. Plant Dis. 85:1181-1182.

The Brazilian strain of Cowpea aphid-borne mosaic virus (CABMV) is a severe pathogen in peanut and a significant problem when distributing germ plasm to other countries. The virus is seedborne at approximately $0.15 \%$ in peanut, depending upon the cultivar, and its detection in seed lots would strengthen quarantine programs. Utilizing $3^{\prime}$ sequence data (GenBank Accession \#AF241233), primers were designed from the coat protein region and evaluated by reverse transcription-polymerase chain reaction (RT-PCR). Use of the forward primer $5^{\prime}$ CGCTCAAACCCATTGTAGAA-3' and reverse primer 5'-TATTGCTTCCCTTGCTCTTTC-3' yielded a 221-bp product. Extracts of thick seed slices and a sample size of 12 to 25 seed showed no significant advantage of RT-PCR over enzyme-linked immunosorbent assay (ELISA) in tests of large seed lots. However, RT-PCR detected more virus in seed than in the number of infected seedlings normally arising in germination tests. Also, RT-PCR was extremely sensitive and detected 1 infected leaf among 99 healthy leaves. In contrast, ELISA detected only one infected leaf among nine healthy leaves.
\end{abstract}

In 1995, Cowpea aphid-borne mosaic virus (CABMV) of the family Potyviridae was reported to infect peanut (Arachis hypogaea L.) in Brazil (6). Leaf symptoms consisted of ring spots and blotches, and virus incidence was high when peanut was intercropped with cowpea (Vigna unguiculata (L.) Walp. subsp. unguiculata). CABMV was seed transmitted at approximately $0.15 \%$ in peanut and $6 \%$ in cowpea (6) and efficiently vectored by aphids (Aphis gossypii Glov. and Toxoptera citricidus Kirk.). In the United States, the National Plant Germplasm peanut collection is maintained at Griffin, GA and receives regular shipments of seed from countries where CABMV is known to be present. Serological detection by direct antigen coating enzyme-linked immunosorbent assay (DAC-ELISA) is used to identify infected plants and detect virus in seed lots. However, a method to assay larger seed lots and groups of plants was needed to improve virus detection sensitivity. Previously, an immunocapture-reverse transcription-polymerase chain reaction (ICRT-PCR) was developed for the large-scale assay for Peanut stripe virus (PStV) and Peanut mottle virus (PeMV) (3). This article presents information on the use of RT-

Corresponding author: A. G. Gillaspie, Jr.

E-mail: s9gg@ars-grin.gov

Accepted for publication 24 June 2001.

Publication no. D-2001-0810-02R

This article is in the public domain and not copyrightable. It may be freely reprinted with customary crediting of the source. The American Phytopathological Society, 2001.
PCR for the detection of CABMV in large numbers of seed and leaf samples.

\section{MATERIALS AND METHODS}

Virus isolates. The Brazilian isolates of CABMV were obtained from peanut plants in Brazil and some from plants grown at Griffin. Peanut seed $(1,553)$ were collected from CABMV-infected plants in Brazil, tested individually for CABMV by DACELISA (1), and sent to Griffin for RT-PCR assays. Samples of 5 to 24 seed were collected from 761 seed and tested by RT-PCR. In addition, a cowpea isolate of CABMV (supplied by R. O. Hampton, USDA-ARS, Oregon State University, Corvallis) was maintained in cowpea cv. Early Ramshorn in a growth chamber. Plants and seed were tested for the presence of CABMV by DACELISA using polyclonal rabbit antisera (1:20,000; supplied by D. M. Rochon, Agriculture and Agri-Food Canada, Summerland, British Columbia).

RT-PCR from total RNA. To initially optimize the primers and reaction conditions for RT-PCR, CABMV-RNA was extracted from leaf tissue as follows: $0.5 \mathrm{~g}$ of tissue was ground in a grinding bag (Agdia Inc., Elkhart, IN) with $5 \mathrm{ml}$ of Qiagen lysis buffer containing guanidine isothiocynanate, mixed with $100 \mu \mathrm{l}$ of $20 \%$ sarkosyl. The extract was heated to $70^{\circ} \mathrm{C}$ and processed through a Qiagen miniprep spin column (Qiagen Inc., Chatsworth, CA) to yield a preparation of total RNA (3). A method using Triton X-405R (Sigma-Aldrich, St. Louis) also was attempted as reported by Singh (7) for Potato leafroll virus. Based on CABMV sequence data (GenBank Accession \#AF241233), primer pairs were designed from the coat protein
(CP) gene and the $3^{\prime}$ untranslated region. Viral cDNA was produced as follows: an RT mix (20 $\mu \mathrm{l}$, consisting of $4 \mu \mathrm{l}$ of $5 \times$ first strand reverse transcription buffer [Gibco BRL Life Technologies, Gathersburg, MD], $2 \mu \mathrm{l}$ of 0.1 $\mathrm{M}$ dithiothreitol, $2 \mu \mathrm{l}$ of $10 \mathrm{mM}$ deoxynucleoside triphosphate [dNTP], $0.5 \mu \mathrm{l}$ of reverse primer [primers at $100 \rho \mathrm{M} / \mu \mathrm{l}], 0.2 \mu \mathrm{l}$ of $\mathrm{RNa}-$ sin RNase inhibitor [Promega Corp., Madison, WI], $0.25 \mu \mathrm{l}$ of SuperScript RNase $\mathrm{H}^{-}$ Reverse Transcriptase [Gibco BRL Life Technologies], $6.05 \mu \mathrm{l}$ of nuclease-free water, and $5 \mu \mathrm{l}$ of total RNA extract) was placed in a $0.5-\mathrm{ml}$ tube and treated at $37^{\circ} \mathrm{C}$ for $1 \mathrm{~h}$, then $94^{\circ} \mathrm{C}$ for $2 \mathrm{~min}$. Viral cDNA was amplified in $25 \mu \mathrm{l}$ of the PCR mix containing $2.5 \mu \mathrm{l}$ of $10 \times$ PCR buffer (Promega Corp.), $3.5 \mu \mathrm{l}$ of 25 $\mathrm{mM} \mathrm{MgCl} 2,2.5 \mu \mathrm{l}$ of $2 \mathrm{mM}$ dNTP, $0.5 \mu \mathrm{l}$ of reverse primer, $0.5 \mu$ of forward primer, 12.3 $\mu \mathrm{l}$ of nuclease-free water, $0.2 \mu \mathrm{l}$ of Taq DNA polymerase, and $3 \mu \mathrm{l}$ of RT product as follows: $94^{\circ} \mathrm{C}, 2 \mathrm{~min} ; 35$ cycles of $94^{\circ} \mathrm{C}, 30 \mathrm{sec}$; $50^{\circ} \mathrm{C}, 30 \mathrm{sec} ; 72^{\circ} \mathrm{C}, 60 \mathrm{sec}$; and $72^{\circ} \mathrm{C}, 10 \mathrm{~min}$. The amplification products were assessed by electrophoresis in $1.5 \%$ agarose gels in TBE buffer ( $89 \mathrm{mM}$ Tris-borate and $2 \mathrm{mM}$ EDTA, $\mathrm{pH}$ 8.3) and stained with ethidium bromide. The band at the predicted size of $221 \mathrm{bp}$ was produced. The c-DNA was extracted from the gel using a QIAquick gel extraction kit (Qiagen Inc.) and sequenced in a model 373A sequencer (Perkin-Elmer/Applied Biosystems, Foster City, CA). The results were compared to published DNA sequences by a BLAST search of GenBank as described previously (2).

Individual peanut seed were subsampled by a modified nondestructive technique (5). A slice was removed from each seed, distal to the radicle, with a razor blade and the slices from several seed were combined and extracted by the Qiagen method.

IC-RT-PCR. Attempts were made to develop an IC-RT-PCR method for CABMV similar to that reported for PStV and PeMV (3). Seed slices were triturated in $1 \mathrm{ml}$ of PBST extraction buffer $(0.137 \mathrm{M} \mathrm{NaCl}, 1$ $\mathrm{mM}$ KH2PO4, $8 \mathrm{mM}$ Na2HPO4, $3 \mathrm{mM}$ $\mathrm{KCl}, 0.05 \%$ Tween-20, $3 \mathrm{mM}$ NaN3 containing $0.01 \mathrm{M}$ Na2SO3, 2\% polyvinylpyrrolidone molecular weight 40,000, 3 $\mathrm{mM}$ NaN3, $2 \%$ powdered milk, and $2 \%$ Tween-20, $\mathrm{pH}$ 7.4) in a grinding bag (Agdia Inc., Elkhart, IN). The slurry was centrifuged at $14,000 \times g$ for $5 \mathrm{~min}$ in a microfuge tube. The aqueous fraction was tested. In ICRT-PCR, CABMV antiserum was used in the PCR tube and the sample was added and incubated. After incubation, tubes were rinsed in PBST, and RT-PCR was performed 
in the same tube. A variation of the procedure was attempted by substituting M-MLV reverse transcriptase (Gibco BRL Life Technologies) for the SuperScript Transcriptase. In addition, a Carboxydothermus hydrogenoformans DNA polymerase one-step RTPCR system (Roche Diagnostics Corp., Chicago) was tested to determine if this approach would help make the viral RNA available for production of cDNA. Also, the QIAQuick Gel Extraction kit (Qiagen Inc.) was used on gel slices taken from the area of the gel of the expected 221-bp band. The resulting sample was reamplified and run on a new gel to detect the possible presence of cDNA below detection threshold in agarose gel assay. Tests to determine the quantity of CABMV attached to the tubes were done by DAC-ELISA in the tubes. In addition, the presence of infectious CABMV attached to the tube was measured by removing virions with vigorous washing in $0.025 \mathrm{M}$ phosphate buffer, $\mathrm{pH} 7.2$, containing $0.1 \%$ sodium dodecyl sulfate and bioassays on cowpea plants. The rub-inoculated plants were rinsed with water and allowed to grow in a greenhouse.

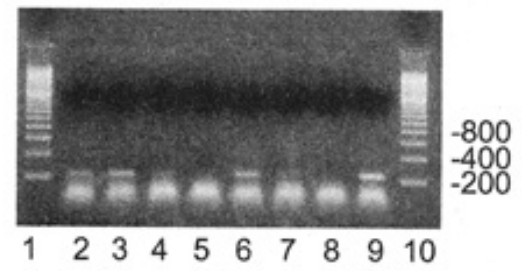

Fig. 1. Reverse transcription-polymerase chain reaction bands in agarose gel with seed-tissue dilutions from Cowpea aphid-borne mosaic virus (CABMV)-infected seed. Lanes 2 to 8 are extracts of 1 infected seed and 4, 9, 14, 24, 49, 74 , and 99 healthy seed, respectively. Lane 9 is the product of an extract from one infected seed. Lanes 1 and 10 include size markers (200-bp ladder). CABMV-specific bands were observed at a marker position of $221 \mathrm{bp}$. The band at $100 \mathrm{bp}$ represented primer material.

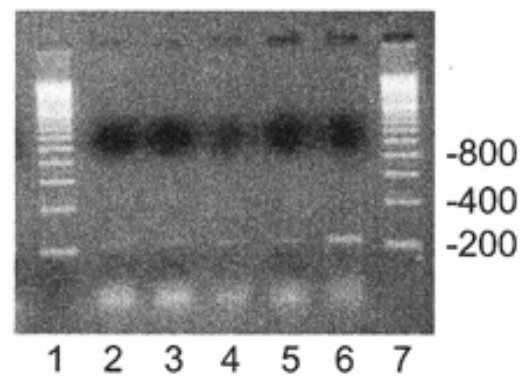

Fig. 2. Reverse transcription-polymerase chain reaction bands in agarose gel with leaf-tissue extracts of Cowpea aphid-borne mosaic virus (CABMV)-infected plants and dilutions with healthy plants. Lanes 2 to 5 are 1 infected plant mixed with $24,49,74$, and 99 healthy plants, respectively. Lane 6 is extract from an infected plant. Lanes 1 and 7 contain size markers (200bp ladder). CABMV-specific bands were observed at a marker position of $221 \mathrm{bp}$. The band at $100 \mathrm{bp}$ represented primer material.

\section{RESULTS AND DISCUSSION}

An RT-PCR method using primers designed from the CP gene of CABMV detected the virus in plants and in seed. The forward primer 5'-CGCTCAAACCCATTGTA GAA$3^{\prime}$ and reverse primer $5^{\prime}$-TATTGCTTCCCT TGCTCTTTC- $3^{\prime}$ from the CP gene coding region produced the expected 221-bp product (Fig. 1). The sequence data of the product matched the sequence for CABMV (data not shown). This primer set was used exclusively in our study because other primer pairs designed from the CABMV CP gene or the untranslated region gave erratic results (data not shown).

Initial attempts to detect CABMV by IC-RT-PCR failed using extracts of leaves and seed. However, using the same conditions, IC-RT-PCR with PStV and PeMV and specific primers were successful. Infectious CABMV was recovered from IC tubes and viral antigens were detected in the IC tubes by DAC-ELISA. Apparently, CABMV RNA was not exposed sufficiently during the IC-RT-PCR process for synthesis of cDNA. Neither the use of MMLV reverse transcriptase nor the $C$. therm. RT-PCR system and dimethyl sulfoxide treatment were useful. Use of the QIAQuick gel extraction kit also failed to detect a PCR product of the expected size. Also, we were unsuccessful in recovering viral RNA with Triton X-405R detergent.

In 1,553 peanut seed pretested by DACELISA, 8 seed (testing positive for CABMV by ELISA) were confirmed by PCR. Also, RT-PCR of another 57 seed samples comprising 5 to 24 seed (total 761 seed) and negative by ELISA showed seven lots to be positive for CABMV (Table 1). Subsequent reassays of individual seeds from seed lots containing 5 , 12 , and 12 seed detected virus in 1,9 , and 3 seed, respectively. Even if one assumes that each ELISA-negative group testing positive contained only one infected seed, the number of seed containing virus as detected by PCR or ELISA (approximately 1 to $2 \%$ ) is greater than the percentage of seed that normally would be expected to produce infected plants (approximately $0.15 \%$ ). However, the seed transmission rates of these plants and virus isolates were not tested.

In general, seed were more difficult to process than leaf tissues, but seed slices of 2 to $4 \mathrm{~mm}$, which included the seed coat as well as the cotyledons, produced more reproducible results by RT-PCR, presuma- bly due to virus in the seed coat or uneven distribution of the virus within the seed. In contrast, PStV and PeMV could be reproducibly detected by RT-PCR from a single seed from 100-seed composites using smaller slices (approximately $1 \mathrm{~mm} ; 5$ ). The 1-mm slices also work well for ELISA with PStV (5). The necessity of 2- to 4-mm thick slices per seed limited the composites to 25 seed (Fig. 1). With ELISA, the detection threshold was one infected and nine healthy seed.

Even though a seed germination step was involved, RT-PCR detected CABMV in a composite of 1 infected leaf and 99 healthy leaves (Fig. 2). In comparison, ELISA detected 1 infected plant in a 20-plant composite in one test, but a dilution of 1 infected plant in a 10-plant composite seemed the highest dilution for dependable results. More viral RNA was detected in dormant seed than is normally required to produce infected plants, which suggests that, in screening imported seed, it is better to germinate the seed and test the seedlings.

\section{ACKNOWLEDGMENTS}

We thank J. Chalkley and D. Pinnow for technical assistance.

\section{LITERATURE CITED}

1. Gillaspie, A. G., Jr., Hopkins, M. S., Pinnow, D. L., and Hampton, R. O. 1995. Seedborne viruses in preintroduction cowpea seed lots and establishment of virus-free accessions. Plant Dis. 79:388-391.

2. Gillaspie, A. G., Jr., Mitchell, S. E., Stuart, G. W., and Bozarth, R. F. 1999. RT-PCR method for detecting Cowpea mottle carmovirus in Vigna germ plasm. Plant Dis. 83:639-643.

3. Gillaspie, A. G., Jr., Pittman, R. N., Pinnow, D. L., and Cassidy, B. G. 2000. Sensitive method for testing peanut seed lots for Peanut stripe and Peanut mottle viruses by immunocapturereverse transcription-polymerase chain reaction. Plant Dis. 84:559-561.

4. MacKenzie, D. J., McLean, M. A., Mukerji, S., and Green, M. 1997. Improved RNA extraction from woody plants for the detection of viral pathogens by reverse transcription-polymerase chain reaction. Plant Dis. 81:222-226.

5. Pinnow, D. L., Chalkley, J. H., and Demski, J. W. 1990. A practical method for the detection of peanut stripe virus in peanut seed. Ga. Agric. Exp. Stn. Rep. 584.

6. Pio-Ribeiro, G., Pappu, S. S., Pappu, H. R., Andrade, G. P., and Reddy, D. V. R. 2000. Occurrence of Cowpea aphid-borne mosaic virus in peanut in Brazil. Plant Dis. 84:760-766.

7. Singh, R. P. 1999. A solvent-free, rapid and simple virus RNA-release method for potato leafroll virus detection in aphids and plants by reverse transcription polymerase chain reaction. J. Virol. Methods 83:27-33.

Table 1. Reverse transcription-polymerase chain reaction (RT-PCR) results with peanut seed collected from Cowpea aphid-borne mosaic virus-infected plants

\begin{tabular}{|c|c|c|c|c|c|}
\hline \multirow[b]{2}{*}{ Peanut line } & \multicolumn{2}{|c|}{ DAC-ELISA ${ }^{a}$} & \multicolumn{3}{|c|}{ RT-PCR } \\
\hline & No. of seed & Result & No. of seed & No. of groups ${ }^{b}$ & Result \\
\hline \multirow[t]{2}{*}{ BRS 151-27 } & 584 & Negative & 246 & 19 & 5 positive, 14 negative \\
\hline & 8 & Positive & 8 & 8 & 8 positive \\
\hline BR 1 & 261 & Negative & 261 & 19 & 19 negative \\
\hline Local cultivar & 700 & Negative & 246 & 19 & 2 positive, 17 negative \\
\hline
\end{tabular}

a Direct antigen coating enzyme-linked immunosorbent assay.

b Number of groups tested; group sizes ranged from 1 seed to groups of 5 to 24 seeds. 